\title{
Letter to the Editor: publish, publish ... cursed!
}

\author{
Antonio Fernandez-Cano ${ }^{1}$ (D)
}

Received: 10 November 2020 / Accepted: 9 December 2020 / Published online: 16 February 2021

(c) Akadémiai Kiadó, Budapest, Hungary 2021

\begin{abstract}
This paper comments on the phenomenon of "publish or perish" associated with the current information explosion and its awful consequence: the curse that hangs over academia which dooms it to publish incessantly irrelevant and pointless documents. The overabundance of publications is not justified and is not even necessary in many contexts for personal promotion, and even less for the advancement of science. Therefore, the current role of scientific journals is highly questionable that its aim could be misleading. Huge numbers of articles are published, but they are not read because the aim is principally "publish for publish," or publication for its own sake. The standard corrective tool for improving scientific communication-peer review-cannot function adequately, and biases and perversions are introduced which undermine society's confidence in the scientific enterprise. A dark landscape unfurls itself across the world of scientific information, forcing us to question and improve its current state. Methodologically this paper goes halfway between the essay and the review trying to provoke engaged and useful controversy.
\end{abstract}

Keywords Publish or perish $\cdot$ Scientific information $\cdot$ Saturated edition $\cdot$ Scientific journals $\cdot$ Peer review

\section{Contextual outline}

I extract the title of this article from the movie They Shoot Horses, Don't They? titled in Spain Danzad, danzad, ... malditos [Dance, dance, cursed!], a film directed by Sidney Pollack (1969), in which a group of desperate contestants during the time of the Great Depression in the U. S. participate in a contest in which they must dance until exhausted, the winners being the last couple left standing. While dancing they can eat and drink, and winning the prize, they would get enough money to continue surviving.

The metaphor is cruel as a Greek tragedy, blunt and hopeless, and its power is transferable to other areas of life; see Fernández-Cano et al. (2012) for the use of Greek myths as interpretive metaphors of research and evaluation fields. One such area is scientific publication, a multi-faceted and extraordinarily complex phenomenon.

Antonio Fernandez-Cano

afcano@ugr.es

1 Department Research Methods and Diagnostics in Education, Faculty of Educational Sciences, University of Granada, Campus de Cartuja, 18071 Granada, Spain 
An initial consideration: this paper, halfway between the essay and the review, contains a series of personal reflections and observations from the specific Spanish context, and it does not try to generalize to other areas. The reader mutatis mutandis could interpret, judge and accommodate these comments to the personal scope.

\section{Publish or perish}

In scientific academia, the Anglo-Saxon dictum "Publish or Perish" has been universally imposed. An aphorism of intricate origin (Garfield 1996), it is used to denote the peremptory need for a scientist, group or institution to accumulate published products to objectify its merits. The topic is so exuberant that it could elaborate a bibliometric study. It has become universal, although, as Mario Bunge (1992) explained, in the Latin world it is also true that "if you publish more than others, you will perish."

The most immediate consequence of "publish or perish" was the information explosion, which some authors tried unsuccessfully to control with proposals that were surpassed or with unachieved proposals (Huth 1989); even from the qualitative methodology realm, additional proposals were raised which pretended to be integrative (Major and Savin-Baden 2010) but were dispersed in a cumbersome and verbose discourse. Chavalarias (2017) analyzes the effects of the "publish or perish" policy, that turns out to have no significant effects in the developments of emerging scientific fields, while having detrimental impacts on the quality of the production of mature fields. At this point, one has the melancholic impression that the current state of scientific information, already on fire and with more wood added every minute by the Internet and its social networks, can be summed up in two words: colossal chaos. Ulrich's Periodicals Directory (2020), an authoritative source of bibliographic and publisher information, indexes more than 300,000 periodicals including all types of academic and scholarly journals.

Quantity is imposed on quality as a biblical curse already anticipated in Ecclesiastes $12: 12$, "To compose many books is never to end, and to study too much harms health" (Catholic Bible of Jerusalem). The academic researcher becomes a kind of modern Sisyphus condemned to publish one article after another as a stone that never reaches the top; hence the description of the phenomenon as a syndrome against which there is a widespread claim (van Dalen and Henkens 2012; Grancay Veinhardt and Sumilo, 2017; Klumpp 2019).

Discovering a relevant finding and subsequently transferring it from the laboratory to the clinical or industrial practice, despite the many failures that this entails (Lyden and Lapchak 2012), are actions of high complexity that fall far from scientific editing. In the context of data science, Beath et al. (2012) manifest that finding value in the explosion of data is a very complex task because the institutions, especially universities, are not succeeding at generating significant business value from their data. From this perspective, assessing the quality of research using the imperturbable quantitative indicators is highly questionable even if these indicators are increasingly used, and increasingly diverse (EC3metrics and Repiso 2018).

One of the many reasons behind this plethora of publications is that they do not yield valid findings, only feeble conclusions; an obvious example of this is the proliferation of studies on COVID-19, while the world awaits anxiously the panacea of a vaccine. A search in the Web of Science-All databases with the Topic field under the term "COVID19" yields a total of 75.036 documents [!] through November, 7th, 2020, in the three core 
domains of research: Science and Technology (53.900), Social Sciences (17.013) and Art and Humanities (886); 99.6\% of them were edited in 2020. In this sense Dinis-Oliveira (2020) speaks of a "paperdemic" related to the COVID-19 research as a problem of academic integrity. This labile topic seems more typical of the social sciences, in which publications abound to the point of having given rise to a synthesis methodology which is metaanalysis, but remember this other methodological dictum: "Garbage in, garbage out", in the absence of conclusive evidence of some meta-analytical integrations.

This hyper-saturated cluster of publications not only releases studies with little methodological validity but above all scarce impact on clinical practice and social transformation; definitively, the validity of research by its use. Reducing the impact of an author's research to simple and primary indicators as the production and citation indicators, or more specifically to the ubiquitous impact factor or to the already also ubiquitous $\mathrm{H}$ index (Hirsch 2005), is mere tautology that can be extended ad libitum to centers, research groups, departments, and countries as a sterile and inconsistent game. To use Google's data related to production and citation indicators is to benefit from the metrical delirium tremens aroused by such citation and production data; see, for example, the fun experiment conducted by Delgado López-Cózar Robinson and Torres-Salinas (2014) on Google's outburst about citing a false and eccentric paper.

Let us avoid here the image of the dung beetle rolling its ball, however big (production) and smelly (citation). The limitations of citation analysis as an indicator of research impact are multiple and quasi ad nauseam (see Fernández-Cano 1995); it is obvious that normal science, in the sense given to it by Kuhn (2012), is eponymized at best or it simply does not cite or reference bibliographically its author(s), in a phenomenon that Merton (1949) called "obliteration by incorporation".

\section{Much publishing is not strictly necessary}

On the other hand, mediocre academic and research careers have been mounted on a paltry and dull scientific production and when these academics reach the intended status, they stop publishing and citing, and of course stop being cited. Enough of these pompous academic careers have developed through mere co-optation, being integrated into cliques, institutionalized favoring, networks of old friends who, for what has come to be called adverse selection, control with stubborn immobility the agencies, juries, evaluation committees, academic and scientific associations, with the blessing of the prevailing political group. These individuals barely offer something relevant even as principal authors, obtaining generous funds from discretionary national and supranational agencies assigned to trivial studies, which must be justified by abundant application forms, and make up subtle power lobbies. In short, this is a parasitic caste not living on the shoulders of giants but lording it over humble and struggling workers, on whom it imposes its irregular and manifestly biased practices with the acquiescence of political and economic interest groups. Its obvious presence in research systems breaks any cumulative advantage and its biases invalidate any alleged valid evaluation or assessment of research; because the Matthew effect, which Merton (1968) postulated, is not verified in them by operating with the simplistic indicators of production and citation, but it is verified in that esoteric indicator that is power because "the powerful becomes more powerful". This parasitic caste has not been the victim of the curse of publishing, they are not cursed, thanks to their enviable subtle displays of social intelligence. 
The overabundance of publications is not justified and is not even necessary in many contexts as arts, social sciences and humanities for personal promotion where even much publishing can involve perishing, as both Relman (1977) and Bunge (1992) explained. The consequences of this pressure have led to bad practices on the part of researchers maddened by the furious itch to publish and that in some countries like China is still magnified (Qiu, 2010). A review of bad practices in scientific publication is available in Helmer Blumenthal and Paschen (2020), such as researchers buying author slots on papers written by others or buying papers from online brokers; researchers turning to predatory publishers to get low-quality work published; plagiarism; duplicate publication; "salami papers," and so on. Ioannidis Klavans and Boyack (2018) have identified scientists who publish a paper every five days, calling them hyper-prolific authors. Between 2001 and 2014 the number of hyper-prolific authors increased from 4 to 81 , while the number of regular authors increased by a factor of 2.5 [sic]. Other spurious interests can be also added: those of predatory publishers of scientific journals, a new sign of an unhealthy publish or perish game (Nielsen and Davison 2020).

Furthermore, there is no strong evidence that eminent scientists have been great publishers. In fact, humanity's most influential transformers (i.e., Christ, Buddha, Socrates, and even Lao-Tse) never wrote anything. Now we lack a compact study which relates productivity and measured prestige by an accepted dummy variable: winning a Nobel Prize. The available studies are quite limited, almost anecdotal and with exceptionally low sample size - fewer than 10 Nobelists. Zuckerman's (1967) early, seminal study showed that Nobel laureates in science publish more than a matched sample of scientists, but that receipt of the Prize is followed by declining productivity. Kademani et al. (2005) state that the Nobel Prize is awarded for an outstanding contribution carried out by scientists in a particular field of scientific activity which will have an everlasting impact and create altogether new fields for research; obviously the Nobel Prize is not gained by authors with a high publication productivity. According to Li, Yin, Fortunato and Wang (2020), the Nobelists' careers before winning the prize follow relatively similar patterns to those of ordinary scientists, being characterized by hot streaks and increasing reliance on collaborations.

Nevertheless, it must be stated that obtaining the Nobel Prize is not the discriminating panacea variable of scientific quality (Raven et al. 2009). Eminent scientists did not achieve such a conspicuous prize; cases of outrageous oblivions are abundant (e. g., the Hungarian Gabor A. Somorjai, the Romanian Gheorghe Benga, both in Chemistry; or the Italians Giovanni Jona-Lasinio and Nicola Cabibbo in Physics; this short relation could clearly be enlarged). A very current case is the Spanish Martínez-Mojica discovering the CRISPR sequence, which was a biotechnological revolution with bacterial origin (see Mojica et al. 2005). In 2020, the Academy gave the prize to two of their followers. The Nobel committee may be rejecting researchers from countries less relevant in science with a bias in favor of countries with great weight in science. We would then be faced with additional evidence of Matthew's effect.

\section{The troubled role of scientific journals}

Since Harry Oldenburg articulated the standards for scientific editing in the mid-seventeenth century through the journal Philosophical Transactions of the Royal Society, scientific periodicals have undergone impressive changes (Hall and Hall 1966; Fyfe McDougall-Waters and Moxham 2015). They went from a naive form, dubbed the Little 
Science, to one very different: crowded, complex, hard, stormy; the Big Science, which were christened so by Price (1986). The scientific periodicals that had been the communication media and social representation of an invisible school (Crane 1972) entered a kind of metastasis such that they continued to grow but with remarkable variations and rhythms according to discipline, making less monolithic the predictable model of the logistical growth of science that Price proposed; see the reviews of studies in Fernández-Cano Torralbo and Vallejo (2004) and Meadows (2000) for a historical perspective on the growth of journal literature.

In the current state of accumulation of scientific documents, one has the melancholy impression that the aim of the journals, which once was to communicate relevant findings and expose useful controversy, became to publish per se but not to be read. The current picture could not be gloomier. The "useful" science, the applied science which moves vast monetary funds, has been enclosed in mostly private corporations that aspire to generate patents and sellable prototypes and sometimes deign to publish their findings in such prominent journals as Science, Cell, and Nature; they are conformed as powerful epidemic lobbies with rejection rates around 95\% (Mukherjee 2018). For a review of acceptance rates of scholarly peer-reviewed journals, see Björk (2019).

What matters to these corporations is the account of benefits born of the voracity typical of insatiable, unthinking capitalism with its quasi-pathological demands, especially in pharmaceutical companies and information and communication technologies (ICTs) firms. Science with economic impact, apart from some academic institutions, is carried out by private corporations with a robust profit motive. "Powerful gentleman is Mister Money" said the Spanish Baroque writer Don Francisco de Quevedo (1984). Thus, in the race for a vaccine against COVID-19, corporations struggle hard to achieve it by investing large resources that they could intend to recover extensively. Science is definitely not an angelic enterprise.

Meanwhile, the rest of those who call themselves scientists, and especially social scientists, have contributed to basic science by consuming public funds and generating labile, speculative knowledge with no real impact. The thirst to publish associated with personal academic promotion has generated more and more journals through the irrepressible phenomenon of the atomization of science, not as a result of real, increasingly specialized scientific advancement, as Ortega y Gasset (1929) so critically and aptly glimpsed, but of its potential agents' perennial need to publish, driven by the hunger for academic and professional promotion.

Subtle ways, then, have emerged to finance the issuing of the journal, from those demanding a direct payment to publish to those cloaking the payment in other artful predatory maneuvers. Most recently, the Open Access modality equates to paying sums for publishing your work, with free access for everyone. The author-worker self-exploits.

Add the deep bias of Anglocentrism, English as the lingua franca of scientific publication for not only the written word but the spoken as well; a researcher who does not speak fluent English becomes an absolute ignorant, one who is muted. The dictum is no longer "publish or perish" but has become: "Pay to publish in English or you will perish." Collateral derivative connotations have been the fall of the national sciences, the disuse of (nonEnglish) national languages, and the irrelevance of domestic journals that end up having at best a function of dissemination of research, a pedagogical task. It could be argued that the scientific publishing program has entered, using the Lakatosian model of program evaluation (Lakatos, 1978), a manifest regression that is becoming degenerative. It is limited, then, only to the hope of the relevant findings, no matter how occasional and even serendipitous they may be (Pérez Tamayo 1980). 
This state of growth overflowing with publications seems to be in tune with humanity's current historical moment, characterized as it is by population overgrowth, overexploitation of natural resources to exhaustion, hyper-consumerism, loss of biodiversity, and the derived climatic alterations that are threatening the habitability of the planet.

\section{The reviewer as a useful slave}

The reviewer as a crucial evaluator of science has become a complex figure of useful slave, or worse, a kind of free hetaera. It is bluntly paradoxical that a journal finds them useful for making multiple and valid revisions yet discards them as soon as they seek to publish their own work in it. They may be generous and even compassionate reviewers but not joyful authors. These young researchers are advised "to normalize" their frustrating experiences (Furnham 2020). Be patient and work hard! Null are the reviewer's rewards, at most a supporting certificate as such on a separate piece of paper or one's name written on the journal's annual final issue. It is no wonder that every day it is more difficult to recruit those (Fox, Albert and Vines 2017), because later they are blinkered by bibliometrics (Stephan Veugelers and Wang 2017). Their availability and sophisticated assignment (i. e. Kalmukov 2020) are more reminiscent of a skilful fishing exercise than the fundamental ready participation that illuminated Oldenburg (1667). Most of these reviewers are bright young people but precarious researchers working altruistically for publishers and other "big guys"; the latter, in contrast to the former, are a band of mediocre people who swarm and vegetate in science but never lose their chairs.

On the other hand, criticism of peer review is huge (Fernández-Cano 1995); for example, the questionable concordance between reviewers who make inter-reviewer reliability scarcely significant and consequent revisions invalid and that is that; a valid review should involve replicating the study being reviewed, and this is very seldom done.

\section{Which future?}

I do not claim the gift of prophecy, but I can make an educated guess with founded insights while still trying not to be dystopian or apocalyptic. Outstanding, fully fledged science will remain primarily in the hands of private corporations; outside of scientific publication and prone to patent registration, very few public institutions will join them. The activity of academia, including universities, could be reduced to some basic research; in the meantime its central research task may be to systematize the knowledge generated by others' research, disseminate that knowledge among its students through efficient teaching, transfer it to society in some way; or better yet, replicate previous studies. A replica study is not reproduction, and its path should not be undervalued; replication in science is not the aberrant reproduction criticized by Bourdieu and Passeron (1970). Replication is the capital essence of science. Ramón y Cajal (1999) recommended it by saying: "... it's worth a thousand times more risking repeating discoveries than giving up any attempt at experimental research..." (p. 81). The crisis of science, especially in typical disciplines of the social sciences, psychology and even medicine, is the crisis of replication. Meta-scientific studies have highlighted the lack of reproduction of published findings and the rationality of this lack in academia; see a review of such studies in Fernández-Cano and Fernández-Guerrero (2009). Acknowledged replica studies should have some place in scientific journals. 
On the other hand, the effectiveness of scientific journals is not questioned here, as they are efficient for the social objectives set for them; they are also victims of the need to publish and be cited, that Sisyphean curse, the subtle yet irresistible pressure from the labile rankings of pseudo-impact (Fernández-Cano et al. 2018). Their situation could worsen if spurious interests, such as publicity, misleading advertising, yellow journalism, or shabby didactics, gain weight in scientific editing. Collateral connotations of this inflation syndrome concern the role of national journals and their national languages, which this role is somewhat undetermined as these journals could be limited to social sciences and humanities research unique to the idiosyncratic context of the country and historical time where they are published.

It is clearly questionable whether research is the central objective of universities, which have grown like mushrooms in autumn with the evident massification of students (Calderon, 2018). The university must rethink its mission "outside the inexorable anachronism of imitating peoples or without authenticity" (Ortega y Gasset 1930, p. 3). Academic institutions should reorient their research role in order to avoid becoming aberrant, parasitic institutions devoid of their main social function: the teaching and training of qualified professionals, a function which has secularly belonged to higher education institutions. The tasks of research and teaching are antagonists in some ways. In a consistent meta-analysis, Hattie and Marsch (1996) demonstrate that there is no relationship between them, concluding that "the common belief that research and teaching are inextricably entwined is an enduring myth. At best, research and teaching are very loose" (p. 529). Research needs an especial seclusion; teaching demands many interactions. Notwithstanding, from the university some small, specialized and highly qualified academic groups may well have their scope of action in basic research so alien to private corporations. Coffee for all? No! Research for all? No!

More complex, then, is the role of public research institutions such as the Russian Academy of Sciences (РАН [Российская Академия Наук], the French Centre National de la Recherche Scientifique (CNRS) [National Centre for Scientific Research], the Italian Consiglio Nazionale delle Ricerche (CNR) [National Research Council], the German Max-Planck-Gesellschaft zur Förderung der Wissenschaften (MPG) society [Max Planck Society for the Advancement of Science], or the less robust Spanish Consejo Superior de Investigaciones Científicas (CSIC) [Higher Council for Scientific Research], which will remain subject to national interests or worse, to the fickleness of the dominant political group in each country without being subjected to the necessary evaluations. The alternative for these public research institutions to operate by projects (such as the efficient but dreadful Manhattan Project) seems remote because these agencies are highly bureaucratic and rooted in the political-social network of national research.

Manifold international proposals, declarations and manifestos for the improvement of research and its diffusion are offered with the aim of fostering research integrity. Consistent research agendas are missing that allows research to be concentrated on relevant topics (Úbeda, Fernández-Cano and Callejas 2019). A new ethos in information science behaviors could and should be emerging. But the problem of scientific communication remains imperturbable; see Smith (2015). The researchers' appetite to publish, and the pressure on them to do so, is intensifying. The process is much more competitive.

Meanwhile, academia can scarcely sustain the overabundance of publications, which is not justified and is not even necessary in many contexts as arts, social sciences and humanities for personal promotion and even less for the advancement of sciences. The dark landscape here questioned about the current state of scientific information must be improved. The corrective tool for improve the scientific edition, the peer review, cannot be operative 
and biases and perversions are coming and undermining the confidence in the scientific enterprise. Nevertheless, the question of scientific editing is subject to a principle of uncertainty because the more we research it, the less we like it; but when we ignore its consideration, the more we miss looking into it. This work is only a modest inquiry that aims to place this unique phenomenon of scientific publication in service of the search for a compassionate, humanized science where there are no curses.

Let me add a personal and final consideration. My claim is not to leave a trace of acrimony and pessimism. Clearly, we live in a distressed time of crisis, but better times surely will come. Meanwhile, an old man as I am, near my retirement, still trying to publish this paper nevertheless cannot help evoking the character (le con) of George Brassens' song (1958), Marinette. Definitively, as Martinent (2020) says, the scientists and above all social scientists as I am, we are people with a bad reputation.

\section{References}

Beath, C., Becerra-Fernandez, I., Ross, J., \& Short, J. (2012). Finding value in the information explosion. MIT Sloan Management Review, 53(4), 18-20.

Björk, B.-C. (2019). Acceptance rates of scholarly peer-reviewed journals: a literature survey. El Profesional de la Información, 28(4), e280407.

Bourdieu, P., \& Passeron, J.-P. (1970). La reproduction. Éléments pour unethéorie du systèmed'enseignement. Paris: Éditions de Minuit. English translation as Reproduction in Education Society and Culture (1990). Thousand Oaks, CA: Sage.

Brassens, G. (1958). Marinette, vynil. Amsterdam, NL: Philips-432257 BE.

Bunge, M. (1992). ¡Qué se jubilen otros! [Let others retire!]. Revista de la Cruz Roja, february-march, 8-9.

Calderon, A. J. (2018). Massification of higher education revisited. Melbourne: RMIT University.

Chavalarias, D. (2017). What's wrong with Science? Scientometrics, 110(1), 481-503.

Crane, D. (1972). Invisible colleges: diffusion of knowledge in scientific communities. Chicago: University of Chicago Press.

Delgado López-Cózar, E., Robinson, N., \& Torres-Salinas, D. (2014). The Google Scholar experiment: How to index false papers and manipulate bibliometric indicators. Journal of the American Society for Information Science and Technology, 65(3), 446-454.

Dinis-Oliveira, R. J. (2020). COVID-19 research: pandemic versus "paperdemic", integrity, values and risks of the "speed science." Forensic Sciences Research, 5(2), 174-187.

EC3metrics-Repiso, R. (2018). Periodic table of scientometric indicators. El Profesional de la Información, 27(3). Available in: https://ec3metrics.com/wp-content/uploads/2018/06/tablaper3.pdf Accessed 21 July 2020.

Fernández-Cano, A. (1995). Métodos para evaluar la investigación en psicopedagogía [Methods for evaluating psychopedagogical research]. Madrid: Síntesis.

Fernández-Cano, A., Torralbo, M., \& Vallejo, M. (2004). Reconsidering Price's model of scientific growth: An overview. Scientometrics, 61(3), 301-321.

Fernández-Cano, A., \& Fernández-Guerrero, I. M. (2009). Crítica y alternativas a la significación estadística en el contraste de hipótesis [Critics and alternatives to statistical significance for hypothesis testing]. Madrid: Arco Libros-La Muralla.

Fernández-Cano, A., Torralbo, M., Vallejo, M., \& Fernández-Guerrero, I. M. (2012). A narrative review of Greek myths as interpretative metaphors in educational research and evaluation. Educational Research Review, 7(3), 238-248.

Fernández-Cano, A., Curiel, E., Torralbo, M., \& Vallejo, M. (2018). Questioning the Shanghai Ranking methodology as a tool for the evaluation of universities: An integrative review. Scientometrics, 116(3), 2069-2083.

Fox, C. W., Albert, A. Y. K., \& Vines, T. H. (2017). Recruitment of reviewers is becoming harder at some journals: A test of the influence of reviewer fatigue at six journals in ecology and evolution. Research Integrity and Peer Review, 2, 3.

Furnham, A. (2020). Publish or perish: rejection, scientometrics and academic success. Scientometrics, on line. Available in: https://link.springer.com/article/10.1007\%2Fs11192-020-03694-0 Accesed 23 June 2020 . 
Fyfe, A., McDougall-Waters, J., \& Moxham, N. (2015). 350 years of scientific periodicals. The Royal Society Journal of History of Science, 69, 227-239.

Garfield, E. (1996). What is the primordial reference for the phrase "Publish or Perish"? The Scientist, 10(12), 11-12.

Grancay, M., Veinhardt, J., \& Sumilo, E. (2017). Publish or perish: How Central and Eastern European economists have dealt with the ever-increasing academic publishing requirements 2000-2015. Scientometrics, 111(3), 1813-1837.

Hall, A. R., \& Hall, M. B. (Eds.). (1966). The correspondence of Henry Oldenburg, (Vol. 2). Madison, WI: University of Wisconsin Press.

Hattie, J., \& Marsh, H. W. (1996). The relationship between research and teaching: A meta-analysis. Review of Educational Research, 66(4), 507-542.

Helmer, S., Blumenthal, D. B., \& Paschen, K. (2020). What is meaningful research and how should we measure it? Scientometrics, 125(1), 153-169.

Hirsch, J. E. (2005). An index to quantify an individual's scientific research output. PNAS, 102(46), $16569-16572$.

Huth, E. J. (1989). The information explosion. Bulletin of the New York Academy of Medicine, 65(6), $647-661$.

Ioannidis, J. P. A., Klavans, R., \& Boyack, K. W. (2018). Thousands of scientists publish a paper every five days. Nature, 561(7722), 167-169.

Kademani, B. S., Kalyane, V. L., Kumar, V., \& Mohan, L. (2005). Nobel laureates: Their publication productivity, collaboration and authorship status. Scientometrics, 62(2), 261-268.

Kalmukov, Y. (2020). An algorithm for automatic assignment of reviewers to papers. Scientometrics, 124(3), 1811-1850.

Klumpp, M. (2019). Sisyphus revisited: Efficiency developments in European universities 2011-2016 according to ranking and budget data. Review of Higher Education, 43(1), 169-219.

Kuhn, T. S. (2012). The structure of scientific revolutions. 50th anniversary (Vol. 4). Chicago: University of Chicago Press.

Lakatos, I. (1978). The methodology of scientific research programmes Philosophical papers (Vol. 1). Cambridge: Cambridge University Press.

Li, J. C., Yin, Y., Fortunato, S., \& Wang, D. S. (2020). Scientific elite revisited: Patterns of productivity, collaboration, authorship and impact. Journal of the Royal Society Interface. Available in: https://oi. org/10.1098/rsif.2020.0135. Accessed 3 Sept 2020.

Lyden, P., \& Lapchak, P. (2012). Sisyphus and translational stroke research. Science Translational Medicine, 156(4), 156ps20.

Major, C. H., \& Savin-Baden, M. (2010). An introduction to qualitative research synthesis: Managing the information explosion in social science research. New York: Routledge.

Martinent, E. (2020). La mauvaise (e) réputation des scientifiques [The bad reputation of scientists]. Ethics, Medicine and Public Health, 15, A-100565, online. Available in: https://www.sciencedirect.com/scien ce/article/abs/pii/S2352552520301031. Accessed 28 July 2020.

Meadows, J. (2000). The growth of journal literature: A historical perspective. In B. Cronin \& H. B. Atkins (Eds.), The web of knowledge: A Festschrift in honor of Eugene Garfield (pp. 87-107). Medford, NJ: Information Today Inc.

Merton, R. K. (1949). Social theory and social structure (original). New York: Free Press.

Merton, R. K. (1968). The Matthew effect in science. Science, 159(3810), 56-63.

Mojica, F. J. M., Díez-Villaseñor, C., García-Martínez, J., \& Soria, E. (2005). Intervening sequences of regularly spaced prokaryotic repeats derive from foreign genetic elements. Journal of Molecular Evolution, 60(2), 174-182.

Mukherjee, D. (2018). 11 Reasons why research papers are rejected. Typeset blog, Medium. Available in: https://blog.typeset.io/. Accessed 23 Sept 2020.

Nielsen, P., \& Davison, R. M. (2020). Predatory journals: A sign of an unhealthy publish or perish game? Information Systems Journal, 30(4), 635-638.

Oldenburg, H. (1667). Advertisement. Philosophical Transactions of the Royal Society of London, 2, 489-490.

Ortega y Gasset, J. (1929). La rebelión de las masas. Madrid: Austral. First English translation as The revolt of the masses (1932). New York: WW Norton.

Ortega y Gasset, J. (1930). Misión de la Universidad. Madrid: Revista de Occidente. First English translation as Mission of University. Foundations of Higher Education (1944). Princeton, NJ: Princeton University Press.

Pérez-Tamayo, R. (1980). Serendipia: ensayos sobre ciencia, medicina y otros sueños [Serendipity: essays on science, medicine and other dreams] (Vol. 1). México: Siglo XXI Editores. 
Pollack, S., Chartoff, R., et al. (1969). They shoot horses, don't they? [Motion picture]. USA: ABC.

Price, D. J. S. (1986). Little science big science... and beyond. New York: Columbia University Press.

Quevedo y Villegas, F. de (1984). Poderoso caballero es don Dinero [Powerful gentleman is Mister Money].

In Poemas satíricos [Satirical poems]. Barcelona: Editorial Nauta. Original edición in Flores de poetas ilustres [Flowers of illustrious poets](1605). Sevilla: Pedro Espinosa (ed.). English translation in Selected poetry of Francisco de Quevedo: A bilingual edition (1999). Chicago: University of Chicago Press.

Qiu, J. (2010). Publish or perish in China. Nature, 463(7278), 142-143.

Ramón y Cajal, S. (1999). Reglas y consejos sobre investigación científica. Los tónicos de la voluntad [The tonic of the will. Rules and advice on scientific research], 13th ed. Madrid: Austral. Original work published in 1898. English translation as Advice for a young investigator (1999). Cambridge, MA: The MIT Press.

Raven, P., King, D., De Waal, F., Brilliant, L., Brooks, R., Diamandis, P., et al. (2009). Open letter to the Nobel Prize committee. NewScientist, 30 September. Available in https://www.newscientist.com/artic le/dn17863-open-letter-to-the-nobel-prize-committee. Accessed 17 July 2020.

Relman, A. S. (1977). Publish or perish—or both. New England Journal of Medicine, 297(13), 724-725.

Smith, A. (2015). Alternative open access publishing models: Exploring new territories in scholarly communication. European Commission. Available in: https://ec.europa.eu/futurium/en/system/files/ged/ oa_report.pdf. Accessed 22 Sept 2020.

Stephan, P., Veugelers, R., \& Wang, J. (2017). Reviewers are blinkered by bibliometrics. Nature, 544(7651), 411-412.

Úbeda-Sánchez, Á. M., Fernández-Cano, A., \& Callejas, Z. (2019). Inferring hot topics and emerging educational research fronts. On the Horizon, 27(2), 125-134.

Ulrich's Periodical Directory (2020). Ulrich's Serials Analysis System. Available in https://www.ulrichsweb .com/. Accessed 14 Oct 2020.

van Dalen, H. P., \& Henkens, K. (2012). Intended and unintended consequences of a publish-or-perish culture: a worldwide survey. Journal of the American Society for Information Science and Technology, 63(7), 1282-1293.

Zuckerman, H. (1967). Nobel laureates in science: patterns of productivity, collaboration and authorship. American Sociological Review, 32(3), 391-403. 